\title{
EVALUATION OF THE EFFECTIVENESS OF CERTAIN IRRIGATING SOLUTIONS ON PULPAL MICROORGANISMS
}

\author{
N. Sukumar Singh ${ }^{1}$, Naorem Satish Kumar Singh², Ningthoukhongjam Rati Devi ${ }^{3}$ \\ ${ }^{1}$ Associate Professor, Department of Dentistry, J. N. Institute of Medical Sciences, Imphal. \\ ${ }^{2}$ Assistant Professor, Department of Dentistry, J. N. Institute of Medical Sciences, Imphal. \\ ${ }_{3}^{3}$ Postgraduate Student, Department of Conservative Dentistry and Endodontics, Jaipur Dental College, Jaipur.
}

\begin{abstract}
Successful root canal involves as thorough cleansing of the root canal with an irrigating solution. Irrigating solutions dissolve necrotic tissues and debris from crevices and in many instances to root canal instruments and acts as lubricants for root canal instruments and makes the negotiation and enlargement of the canal far easier and reduces the possibility of instrument breakage. Although many author advocate use of different irrigating solution. Less was published regarding the use of combination of $0.2 \%$ Chlorhexidine and neutral EDTA as an irrigating solution. Study was performed in 80 single rooted teeth and irrigated using $0.2 \%$ Chlorhexidine, neutral EDTA, combination of both and $0.9 \%$ normal saline which is control group at different time appointment. It was found out that the reduction percentage in the teeth treated with $0.2 \%$ chlorhexidine within the canal after 15 mins., 48 hrs. and 96 hrs. are 58.78\%, 79.97\% and $90.35 \%$ respectively. The reduction percentage in that of neutral $0.2 \%$ EDTA at the same interval appointments were $21.52 \%, 29.14 \%$ and $40.30 \%$ respectively. The reduction percentage in microorganisms treated with combination of both solution after 15 mins., 48 hours and 96 hours were $89.96 \%, 92.96 \%$ and $95.41 \%$ respectively. This concludes that use of combination of $0.2 \%$ chlorhexidine and neutral EDTA was found to be the most suitable irrigating solution in success of root canal treatment.
\end{abstract}

\section{KEYWORDS}

Chlorhexidine, EDTA, Irrigation, Microorganisms.

HOW TO CITE THIS ARTICLE: Singh NS, Singh NSK, Devi NR. Evaluation of the effectiveness of certain irrigating solutions on pulpal microorganisms. J. Evolution Med. Dent. Sci. 2016;5(74):5478-5483, DOI: 10.14260/jemds/2016/1240

\section{INTRODUCTION}

With the advancement of Endodontics, it has been made possible to save those teeth that were once thought to be beyond repair and have a relatively bad prognosis. The main tool regarding this that came into limelight is the root canal treatment. 1

The primary aim and objective of root canal treatment is the retention of pulp less or pulpally involved tooth with its association of periapical tissue in a healthy state.2,3 Achievement of this objective necessitate that the pulpal space and their contents be eliminated as source of irritation. Irritants contained in these spaces are protein degrading products and microorganisms living and growing in the decomposed tissue. They evoke inflammatory responses in adjacent tissues. ${ }^{4,5}$

A thorough debridement and canal preparation procedure should be given the highest priority in the hierarchy of the root canal treatment. Mechanical instrumentation and irrigation using irrigating solutions greatly enhance the effectiveness of the preparation of the root canal obturation. 6

Irrigating solutions dissolve necrotic tissues and debris from crevices and in many instances to root canal instruments. It also acts as lubricants for root canal instruments and makes the negotiation and enlargement of the canal far easier and reduces the possibility of instrument breakage.7,8

Financial or Other, Competing Interest: None.

Submission 24-08-2016, Peer Review 06-09-2016,

Acceptance 08-09-2016, Published 15-09-2016.

Corresponding Author:

Dr. Naorem Satish Kumar Singh,

\#79/10 Nagamapal Singjubung Leirak,

Imphal West-795001, Manipur.

E-mail:drnsatish@gmail.com

DOI: $10.14260 /$ jemds $/ 2016 / 1240$
Clinical usefulness of bacteriological control in endodontic therapy has been demonstrated by the great success rate, which occurs in teeth filled after obtaining a negative culture.8,9,10 The microbial control within the pulpal tissue and the root canal space is a pre-requisite for the prevention and treatment of pulpal and periapical breakdown. Unfortunately, it is difficult to eliminate all microorganisms and organic debris from the root canal system regardless of the irrigant and instrumentation. ${ }^{11,12}$

In the present study, the antibacterial effect of certain irrigating solutions have been compared in the treatment of teeth with necrotic pulp. ${ }^{13}$ The efficacy of the treatment has been evaluated with bacteriologic methods.

\section{AIMS AND OBJECTIVE}

The purpose of this study is to evaluate the antibacterial effect of two different irrigating solutions, i.e. $0.2 \%$ chlorhexidine and neutral EDTA at the microorganisms in pulp cavity in different time period of irrigations.

\section{MATERIALS AND METHODS}

For the study, single rooted non-vital anterior teeth with necrotic pulps and intact pulp chamber walls were the criteria for the case selection. Oral prophylaxis was done of the selected segment and 80 positive samples were taken for the study. The patients were divided into experimental group for the use of three different irrigating solution, i.e. chlorhexidine, EDTA and combination of chlorhexidine and EDTA and a control which uses normal saline. They were asked to rinse their mouth with chlorhexidine mouthwash twice or thrice daily. The tooth from which the sample was to be taken was cleaned with pumice and isolated using rubber dam.

The tooth and the clamp were cleansed with $30 \%$ hydrogen peroxide for 1 minute. ${ }^{14,15}$ An initial opening was 
made, 1 to $2 \mathrm{~mm}$ into the dentin with a sterile fissure bur at high speed. The tooth was swabbed with hydrogen peroxide for 10 seconds followed by application of $2 \%$ tincture of iodine for 1 minute. The iodine was deactivated with $5 \%$ sodium thiosulphate.

For proceeding the penetration of the roof of the pulp chamber, a sterile No. 2 or No. 4 tungsten carbide round bur was used at slow speed, working the bur from the lingual surface to expose the pulp chamber. ${ }^{16,17}$

After the exposure of pulpal roof, the pre-irrigant sample fluid from the canal was soaked up by absorbent paper point (Dentsply) and transferred to a bottle containing $15 \mathrm{~mL}$ thioglycolate (Dynamicro GR Thane West, Mumbai). ${ }^{16}$ After biomechanical preparation of the root canal for 15 minutes. The irrigating solution was introduced into the canal by means of a sterile syringe and a 27-gauge needle that was not allowed to bind to the canal walls. For every group, culture was taken in the following way. In both groups, $9 \mathrm{~mL}$ of irrigating solution was used by three instalments of $3 \mathrm{~mL}$ each. After 15 minutes, the final irrigation was done with corresponding irrigating solution and a specimen for microbiological examination was taken as post-irrigant sample.

After 48 hours and 96 hours, the patient was called for second appointment. Another specimen for microbiological examination was collected after 15 minutes of instrumentation and irrigation at the end of the second appointment.

The pre-irrigant and post-irrigant samples were streaked on separate blood agar plates. Plates were incubated at $37^{\circ} \mathrm{C}$ for 72 hrs. in an anaerobic chamber (Dynamicro Gaspak System). After incubation Colony Forming Units (CFU) were counted on the plate with colony counter. The organisms were identified by standard microbiological procedures. 10,17

\section{OBSERVATION AND RESULTS}

For the study, eighty single rooted teeth with necrotic pulp were randomly selected from patients attending dental needs at the hospital. None of the patients were on antibiotic therapy for at least three months before or during sample collection. Samples were divided into four groups of twenty teeth each categorising three experimental and one control group namely, A1 (Irrigant $0.2 \%$ chlorhexidine gluconate), A2 (Neutral $0.2 \%$ EDTA), A3 $(0.2 \%$ Chlorhexidine gluconate + Neutral $0.2 \%$ EDTA) and control group B $(0.9 \%$ normal saline). Strict aseptic technique was carried out throughout the study. Every tooth was treated in three appointments and four samples were collected from the same patient at the interval of pre irrigation, after 15 minutes of first irrigation, after 48 hours (Second irrigation) and after 96 hours (Third irrigation); $9 \mathrm{~mL}$ of desired irrigating solution was used for each appointment.

It was observed that bacterial flora (Anaerobic) present in the root canal were streptococcus viridans, enterococcus, staphylococcus albus, peptostreptococcus, bacteroides species and fusobacterium species. The microbial growth within the root canal before irrigation and after irrigation in all four groups were quantitatively analysed and studied. The results showed that the number of post irrigant positive cultures $(\mathrm{CFU} / \mathrm{mL})$ was significantly reduced in all four groups $(\mathrm{P}<0.001)$ compared with the pre-irrigant positive culture using t-test.
In sub-group, all the samples show positive culture report in pre irrigation sample. Post irrigation sample of $0.2 \%$ chlorhexidine gluconate after 15 minutes shows reduction of microorganism. Here, sample taken after 48 hours showed negative culture in two samples, whereas the sample taken after 96 hours showed negative culture in four samples. The reduction percentage in the teeth treated with $0.2 \%$ chlorhexidine within the canal after 15 mins., 48 hrs. and 96 hrs. are $58.78 \%, 79.97 \%$ and $90.35 \%$ respectively. The reduction percentage in that of neutral $0.2 \%$ EDTA at the same interval appointments were $21.52 \%, 29.14 \%$ and $40.30 \%$ respectively (Table I).

In post irrigation sample of $0.2 \%$ chlorhexidine + Neutral $0.2 \%$ EDTA after 15 minutes showed reduction of microorganism, but after 48 hours five samples negative culture, whereas after 96 hours showed eight negative culture. The reduction percentage in microorganisms treated with this solution after 15 mins., 48 hours and 96 hours were $89.96 \%, 92.96 \%$ and $95.41 \%$ respectively (Table I).

In controlled group where samples were treated with $0.9 \%$ normal saline showed increase in microorganisms in nine samples after 48 hours (Second irrigation) and eight samples after 96 hours (Third irrigation). The reduction percentage with $0.9 \%$ normal saline at the same interval appointments were $60.84 \%, 65.62 \%$ and $57.55 \%$ respectively (Table I).

\begin{tabular}{|c|c|c|c|}
\hline Group & $\begin{array}{c}\text { 15 mins. } \\
\text { (First } \\
\text { Irrigation) }\end{array}$ & $\begin{array}{c}\mathbf{4 8} \text { hrs. } \\
\text { (Second } \\
\text { Irrigation) }\end{array}$ & $\begin{array}{c}\text { 96 hrs. } \\
\text { (Third } \\
\text { Irrigation) }\end{array}$ \\
\hline A1 & 58.78 & 79.97 & 90.35 \\
\hline A2 & 21.52 & 29.14 & 40.30 \\
\hline A3 & 89.96 & 92.96 & 95.41 \\
\hline B & 60.84 & 65.62 & 57.55 \\
\hline
\end{tabular}

Table I: Intergroup Comparison in Percentage Reduction

After applying $0.2 \%$ chlorhexidine gluconate, mean and standard deviation of the value of each stages showed that there is a declining trend from pre irrigation to the respective post irrigation stages with the lowest value observed at post irrigation after 96 hours (Table II). T-test showed highly significant deduction from one stage irrigation to another stage irrigation (Table III).

\begin{tabular}{|c|c|c|c|c|c|}
\hline $\begin{array}{c}\text { Sl. } \\
\text { No. }\end{array}$ & $\begin{array}{c}\text { Irrigation } \\
\text { Time }\end{array}$ & $\begin{array}{c}\text { Sample } \\
\text { Size }\end{array}$ & Mean & S.D. \\
\hline 1 & I & Pre (0 hr.) & 20 & 11267600 & 30492168 \\
\hline 2 & II & Post (15 mins.) & 20 & 4893940 & 12158107 \\
\hline 3 & III & Post (48 hrs.) & 20 & 2256660 & 5966642 \\
\hline 4 & IV & Post (96 hrs.) & 20 & 1086400 & 2747354 \\
\hline \multicolumn{5}{|c|}{ Table II: Distribution of Mean of Subgroup A1 } \\
Irrigated by 0.2\% Chlorhexidine with Respect \\
to the Pre and Post Irrigations \\
\hline
\end{tabular}

\begin{tabular}{|c|c|c|c|c|}
\hline Between & t-Value & d.f. & p-Value & Remark \\
\hline I\&II & 4364.58 & 38 & $<0.001$ & VHS \\
\hline I\&III & 6673.96 & 38 & $<0.001$ & VHS \\
\hline I\&IV & 7897.44 & 38 & $<0.001$ & VHS \\
\hline II\&III & 4903.83 & 38 & $<0.001$ & VHS \\
\hline II\&IV & 4410.48 & 38 & $<0.001$ & VHS \\
\hline III\&IV & 1772.91 & 38 & $<0.001$ & VHS \\
\hline \multicolumn{5}{|c|}{ Table III: Result of T-Test of Table II } \\
\hline
\end{tabular}




\begin{tabular}{|c|c|c|c|c|c|}
\hline $\begin{array}{c}\text { Sl. } \\
\text { No. }\end{array}$ & $\begin{array}{c}\text { Irrigation } \\
\text { Time }\end{array}$ & $\begin{array}{c}\text { Sample } \\
\text { Size }\end{array}$ & Mean & S.D. \\
\hline 1 & I & Pre (0 hr.) & 20 & 12826000 & 30101516 \\
\hline 2 & II & Post (15 mins.) & 20 & 10064915 & 20777194 \\
\hline 3 & III & Post (48 hrs.) & 20 & 9088545 & 18880982 \\
\hline 4 & IV & Post (96 hrs.) & 20 & 7881510 & 16365978 \\
\hline \multicolumn{5}{|c|}{ Table IV: Distribution of Mean S.D. of Subgroup A2 } \\
Irrigated by Neutral O.2\% EDTA with Respect \\
to Pre and Post Irrigation \\
\hline
\end{tabular}

\begin{tabular}{|c|c|c|c|c|}
\hline Between & t-Value & d.f. & p-Value & Remark \\
\hline I\&II & 1695.69 & 38 & $<0.001$ & VHS \\
\hline I\&III & 2389.43 & 38 & $<0.001$ & VHS \\
\hline I\&IV & 4030.34 & 38 & $<0.001$ & VHS \\
\hline II\&III & 691.51 & 38 & $<0.001$ & VHS \\
\hline II\&IV & 1596.52 & 38 & $<0.001$ & VHS \\
\hline III\&IV & 399.59 & 38 & $<0.001$ & VHS \\
\hline \multicolumn{5}{|c|}{ Table V: Result of T-Test of Table III } \\
\hline
\end{tabular}

In the case of neutral $0.2 \%$ EDTA, there is also sharp decrease in microorganisms over four different stages of irrigations with the lowest value at after 96 hours irrigation (Table III). T-test showed highly significant different population of microbial flora between the combinations of IV different irrigation stages (Table IV). Similarly, in case of irrigation used in combination of $0.2 \%$ chlorhexidine gluconate and neutral $0.2 \%$ EDTA observed sharp decrease in microbial flora from pre irrigation to different interval stages of post irrigation (Table V). Quite interestingly it is observed that in the case of control group, the number of organisms sudden fall from pre irrigation at 15 mins. after irrigation then little decrease in after $48 \mathrm{hrs}$. irrigation and later rises after 96 hrs. of post irrigation. The variation of mean values of microorganisms for 4 groups understudied with respect to 4 stages of irrigation were variably seen and can be decided using two way Variance ratio test. There is no variation of mean among groups despite visible difference, as $\mathrm{F}=1.23$ for 3,9 d.f. at $5 \%$ probability is insignificant.

\begin{tabular}{|c|c|c|c|c|c|}
\hline $\begin{array}{c}\text { Sl. } \\
\text { No. }\end{array}$ & $\begin{array}{c}\text { Irrigation } \\
\text { Time }\end{array}$ & $\begin{array}{c}\text { Sample } \\
\text { Size }\end{array}$ & Mean & S.D. \\
\hline 1 & I & Pre (0 hr.) & 20 & 61776522 & 222896976 \\
\hline 2 & II & Post (15 mins.) & 20 & 6046382 & 16408546 \\
\hline 3 & III & Post (48 hrs.) & 20 & 4395607 & 11583069 \\
\hline 4 & IV & Post (96 hrs.) & 20 & 502145 & 1272527 \\
\hline \multicolumn{3}{|c|}{ Table VI: Distribution of Mean S.D. of Sub Group A3 } \\
Irrigated by 0.2\% Chlorhexidine Gluconate + Neutral 0.2\% \\
EDTA with Respect to Pre and Post Irrigation \\
\hline
\end{tabular}

\begin{tabular}{|c|c|c|c|c|}
\hline Between & t-Value & d.f. & p-Value & Remark \\
\hline I\&II & 57731.69 & 38 & $<0.001$ & VHS \\
\hline I\&III & 16758.28 & 38 & $<0.001$ & VHS \\
\hline I\&IV & 242918.39 & 38 & $<0.001$ & VHS \\
\hline II\&III & 1395.36 & 38 & $<0.001$ & VHS \\
\hline II\&IV & 5626.72 & 38 & $<0.001$ & VHS \\
\hline III\&IV & 15435.38 & 38 & $<0.001$ & VHS \\
\hline \multicolumn{5}{|c|}{ Table VII: Result of T-Test of Table VI } \\
\hline
\end{tabular}

\begin{tabular}{|c|c|c|c|c|c|}
\hline $\begin{array}{c}\text { Sl. } \\
\text { No. }\end{array}$ & & Irrigation Time & Sample Size & Mean & S.D. \\
\hline 1 & I & Pre (0 hr.) & 20 & 1183150 & 3035438 \\
\hline 2 & II & Post (15 mins.) & 20 & 463306 & 1439966 \\
\hline 3 & III & Post (48 hrs.) & 20 & 406723 & 1218597 \\
\hline 4 & IV & Post (96 hrs.) & 20 & 502145 & 1272527 \\
\hline \multicolumn{6}{|c|}{ Table VIII: Distribution of Mean S.D. of Sub Group B } \\
Irrigated by 0.9\% Normal Saline with Respect \\
to Pre and Post Irrigation \\
\hline
\end{tabular}

\begin{tabular}{|c|c|c|c|c|}
\hline Between & t-Value & d.f. & p-Value & Remark \\
\hline I\&II & 1521.72 & 38 & $<0.001$ & VHS \\
\hline I\&III & 1683.50 & 38 & $<0.001$ & VHS \\
\hline I\&IV & 1467.33 & 38 & $<0.001$ & VHS \\
\hline II\&III & 155.19 & 38 & $<0.001$ & VHS \\
\hline II\&IV & 138.74 & 38 & $<0.001$ & VHS \\
\hline III\&IV & 273.20 & 38 & $<0.001$ & VHS \\
\hline \multicolumn{7}{|c|}{ Table IX: Result of T-Test of Table VII } \\
\hline
\end{tabular}

\begin{tabular}{|c|c|c|c|c|}
\hline Group & 0 hr. & 15 mins. & 48 hrs. & 96 hrs. \\
\hline A1 & 61776522 & 6046382 & 4395607 & 502145 \\
\hline A2 & 12826000 & 10064915 & 9088545 & 7881510 \\
\hline A 3 & 11267600 & 4893940 & 2256660 & 1086400 \\
\hline B & 1183150 & 463306 & 406723 & 502145 \\
\hline \multicolumn{5}{|c|}{$\begin{array}{c}\text { Table X: Distribution of Means of } \\
\text { Organisms over the Groups }\end{array}$} \\
\hline
\end{tabular}

\begin{tabular}{|c|c|c|c|c|c|c|}
\hline $\begin{array}{c}\text { Source of } \\
\text { Variation }\end{array}$ & S. S & d. f. & M. S. S. & $\begin{array}{c}\text { F- } \\
\text { Value }\end{array}$ & $\begin{array}{c}\text { P- } \\
\text { Value }\end{array}$ & Remarks \\
\hline $\begin{array}{c}\text { Due to } \\
\text { Groups }\end{array}$ & 683016318.5 & 3 & 227672106 & 1.23 & $>0.05$ & Insignificant \\
\hline $\begin{array}{c}\text { Due to } \\
\text { Stage }\end{array}$ & 966835809 & 3 & 322278603.2 & 1.748 & $>0.05$ & Insignificant \\
\hline Error & 1659328216 & 9 & 184369801.8 & & & \\
\hline \multicolumn{7}{|c|}{ Table XI: ANOVA on the Data of Table IX } \\
\hline
\end{tabular}

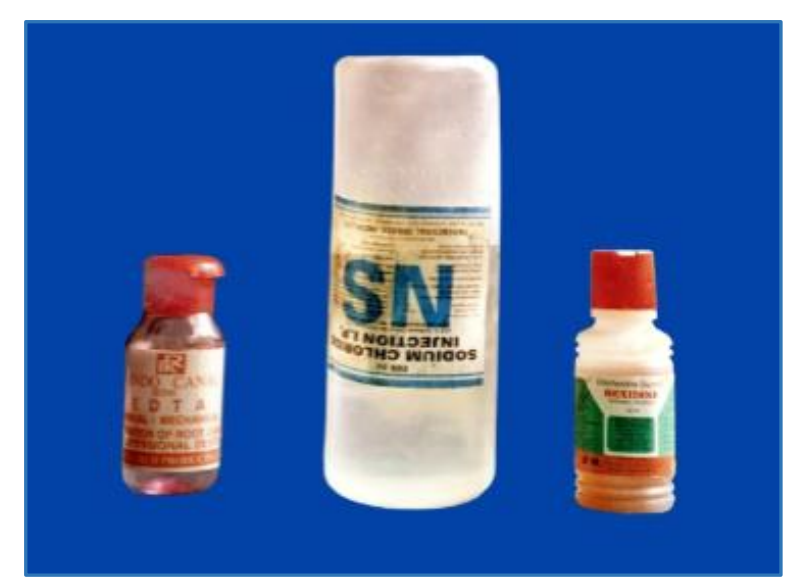

Picture 1: Different Irrigants used in the Study

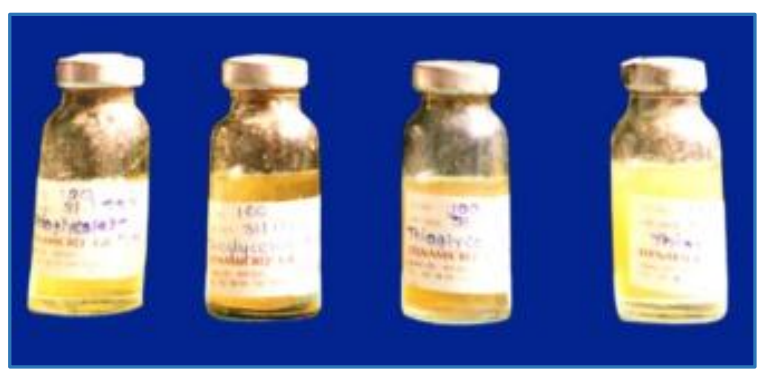

Picture 2: Transport Media 


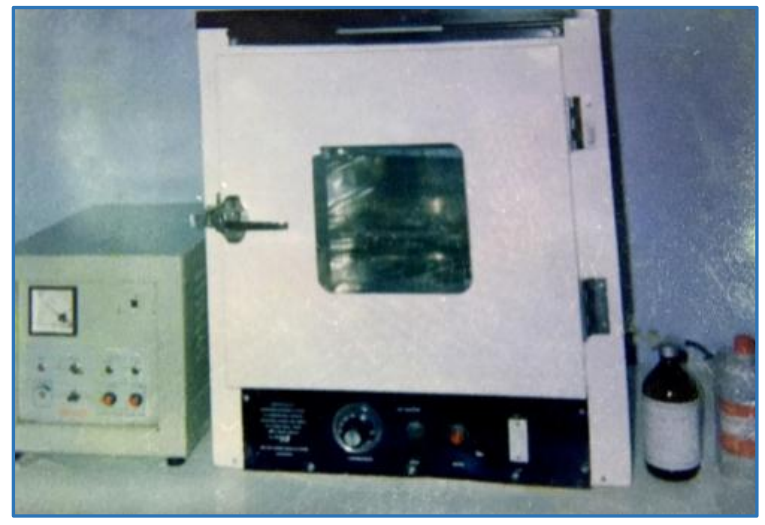

Picture 3: Incubator

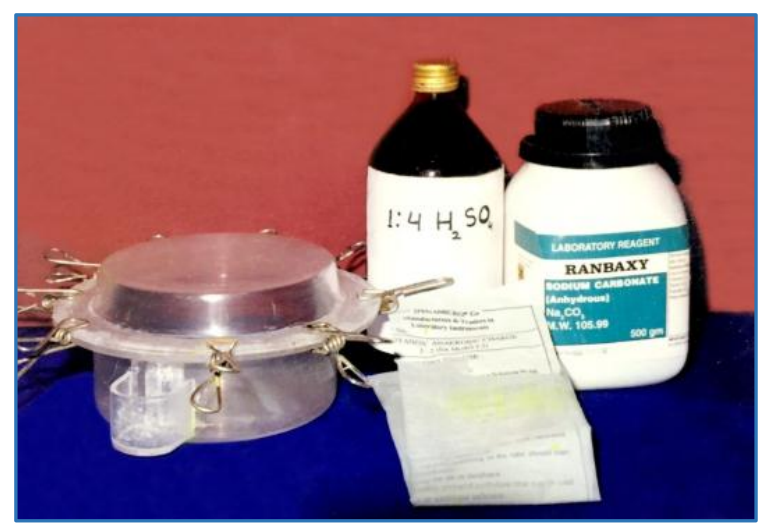

Picture 4: Anaerobic Gas Tank

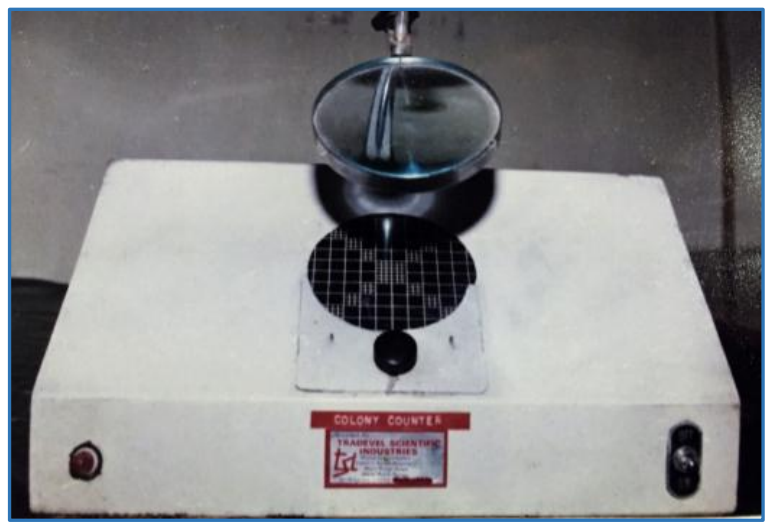

Picture 5: Colony Counter

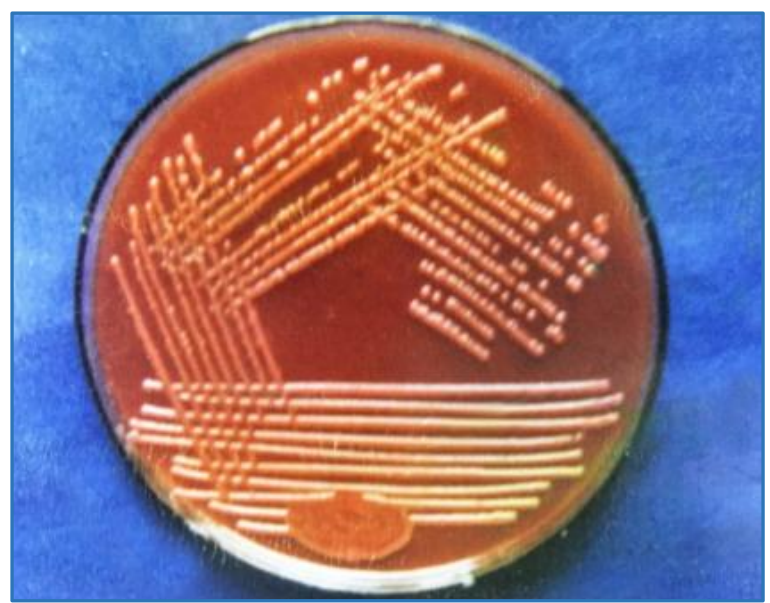

Picture 6: Bacterial Colony

\section{DISCUSSION AND CONCLUSION}

To achieve the desired goal of root canal treatment, L.I. Grossman ${ }^{18}$ described three phases of treatment, i.e. biomechanical preparation, chemical preparation and sterilisation. Ingle and Zeldow ${ }^{17}$ have shown that mechanical enlargement and shaping of the root canal are the first giant step towards a clean and aseptic pulp cavity. During enlargement and shaping, irrigation of root canal is necessary to remove both hard and soft tissues by washing out and removing microorganisms to prevent pulpal and periapical infections. Studies have shown that infected root canals are mainly of anaerobic microorganisms ${ }^{11,19,17}$ (90\%) and are the main cause of pain, swelling, sinus tract formation and halitosis.16,20,1,21 Various irrigants have been used in root canal therapy to reduce or eliminate bacteria, many of them have shown varying degrees of antibacterial activity. In this study, four irrigating solutions have been taken to see their efficacy on root canal viz. chlorhexidine, EDTA, chlorhexidine + EDTA and normal saline.

The result of this study indicates that chlorhexidine and EDTA combination showed greater percentage of reduction of microbial flora (95.4\%) when compared with the individual use of chlorhexidine or EDTA.

Chlorhexidine was found to be more effective in its antibacterial property when compared with EDTA with a percentage reduction of $90.35 \%$ after 96 hours irrigation from first irrigation in case of chlorhexidine, while EDTA comparatively have a less percentage of reduction of $40.3 \%$ after 96 hours. The different data of mean and standard deviation for different groups at different time period showed significant reduction of microbial counts, which was confirmed with S. Patterson et $\mathrm{al}^{22}$ and Vahdaty et $\mathrm{al}^{23}$ study of antibacterial property of chlorhexidine. Chlorhexidine, a cationic bis-guanide has optimal microbial action in between pH 5.5 to 7. It has been found to be effective against a variety of microorganisms, such as gram +ve and gram -ve bacteria, bacterial spores, lipophilic virus, yeast and dermatophytes being bacteriostatic at low concentration and bactericidal at high concentration. In addition to this, acidic protein such as hydroxyapatite absorbs chlorhexidine and releases it gradually in the form of active cation (substantivity), justifying its clinical use as a root canal irrigating solution at different concentration both in vitro and vivo. ${ }^{24,21,25}$

Neutral EDTA was found to be effective against root canal flora as an irrigating solution. In our study, it was found to be statistically significant in different time period of irrigation. Nikiforuk et $\mathrm{al}^{26}$ also established that EDTA being a good chelating agent causes demineralisation of hard tissue at neutral $\mathrm{pH}$. On the contrary, Heling B. et al ${ }^{27}$ found out to be neither bactericidal nor bacteriostatic, but it inhibits the growth of bacteria and eventually destroys bacteria by starvation. It produce no deleterious effect rather its use as an irrigant facilitated biomechanical preparation, as it removes loose debris and softened partially calcified necrotic pulp remnants. Its only drawback is that it makes radicular wall more permeable to microorganism diffusion, because of its chelating property. ${ }^{2,19}$ We have found in our study that EDTA as irrigating solution has no deleterious effect on the tissue, so it can be used as an irrigant. ${ }^{21}$

It may be further emphasised that the combination of EDTA and Chlorhexidine ${ }^{9}$ proved to be even better irrigant as 
they suffice to the potentiality of both the irrigants. It acts synergistically by enhancing the bactericidal effect of chlorhexidine after the debridement and removal of smear layer by EDTA. It also prevents further demineralisation effect of EDTA, which is proportional to the exposure time, thereby increasing the efficacy of the said combination. It may be further emphasised that the combination of EDTA and chlorhexidine proved to be an even better irrigant as compared to EDTA and chlorhexidine individually. In our study, we have found that the combination of chlorhexidine and EDTA show reduction percentage 89.96 after 15 mins., 92.96\% after 48 hrs. and $95.41 \%$ after 96 hours. The mean and standard deviation shows highly significant value in all the time period $(\mathrm{p}<0.001)$. It may be attributed to the reasons that both suffice to the potentiality of both irrigants. EDTA and Chlorhexidine act synergistically. ${ }^{28}$ Though there was not much research regarding the use of chlorhexidine and EDTA combination as irrigating solution. From the findings of this study, we can evaluate the use of these as irrigating solution. From the findings of this study, we can evaluate the use of these as irrigating solution.

In the control group though there was reduction of bacteria in pre and post irrigation group, but there was not much difference found after 48 and 96 hours. So the reduction percentage for this group was found $60.84 \%$ after 15 mins., $65.62 \%$ after $48 \mathrm{hrs}$. and $57.55 \%$ after $96 \mathrm{hrs}$. The mean and standard deviation in different time group and statistical analysis was found to be not significant (Table VII). The decrease of root canal flora in pre and post irrigation may be due to its ability to flush out debris from the root canal rather than having any anti-microbial property. It is also noted that after repeated irrigation with saline, microorganism culture remained positive.

Within the limitations of this study, it may be concluded that the most suitable irrigating solution would be the combination of $0.2 \%$ chlorhexidine and neutral EDTA followed by $0.2 \%$ Chlorhexidine, then $0.9 \%$ normal saline and lastly neutral EDTA. Since this study was conducted in small sample size with few irrigating solutions further study may be needed with larger sample with different irrigating solution in varied time period and concentration to come up with definite conclusion.

\section{REFERENCES}

1. Abraham S, Raj JD, Venugopal M. Endodontic irrigants: a comprehensive review. J Pharm Sci \& Res 2015;7(1):5-9.

2. Abirami CP, Rao SCV. Evaluation of antibacterial activities of root canal irrigants: an in-vitro study. Journal of Endodontology 1999;11:27-29.

3. Torabinejad M, Handysides R, Khademi AA, et al. Clinical implications of the smear layer in endodontics: a review. Oral Surg Oral Med Oral Pathoral Radio Endod 2002;94(6):658-66.

4. Zamany A, Safavi K, Spangberg LS. The effect of chlorhexidine as an endodontic disinfectant. Oral Surg Oral Med Oral Path Oral Radiol Endod 2003;96(5): 578-81.

5. Hill PK. Endodntics. Journal Prost Dent 1959;9:142.

6. Ingle $\mathrm{JI}$, Zeldow $\mathrm{BJ}$. An evaluation of mechanical instrumentation and irrigative culture in endodontic therapy. JADA 1958;57(4):471-6.
7. Aurenbach NB. Antibiotic versus instrumentation in Endodontics. N Y State Dent Journal 1953;19:225-8.

8. Griffee MB, Patterson SS, Miller CH, et al. Relationaship of bacteriodesmelaninogenicus to symtomsaaociated with pulpal necrosis. Oral Surgery Oral Medical Oral Pathology 1980;50(5):457-61.

9. Gutierrez Jh, Villena F, Jofre A, et al. Bacterial infiltration of dentin as influenced by proprietary chelating agents. J Endod 1982;8(10):448-54.

10. Cruickshank R, Duguid JP, Swain RHA. Medical microbiology. A guide to the laboratory diagnosis and control of infections. Edinburgh, London, U.K: E \& S Livingstone Ltd 1965.

11. Darrag AM. Effectiveness of different final irrigating solution on smear layer removal in intraradicular dentin. Tanta Dental Journal 2014;11(2):93-99.

12. Grossman Li. Root canal therapy. $4^{\text {th }}$ edn. Philadelphia: Lea and Febiger 1955:202.

13. Hashem AAR, Ghoneim AG, Lutfy RA, et al. The effect of different irrigating solutions on bond strength of two root canal-filling systems. J Endod 2009;35(4):537-40.

14. Balaji TS. Effect of various root canal irrigants on removal of smear layer and debridement: an SEM study. Pak Oral Dental J 2010;30:205-11.

15. Yelsilsoy C, Whitaker E, Cleveland D, et al. Antibacterial and toxic effects of established potential root canal irrigants. Journal of Endodontics 1995;21(10):513-5.

16. Engstrom B, Lunberg M. The correlation between positive culture and the prognosis of root canal therapy after pulpectomy. Odontol Rev 1965;16(3):193-203.

17. Sundqvist G. Bacteriological studies of necrotic dental pulp. Dr.Odont thesis, University of Umea, Umea, Sweden 1976.

18. Davies A. The mode of action of chlorhexidine. Journal of Periodontology Res 1973;8(S12):68-75.

19. Nicholls SE. The efficacy of cleansing of root canal. British Dent J 1962;112:167-70.

20. Fardai 0, Turnbull RS. A review of literature on use of chlorhexidien in dentistry. JADA 1986;112(6):863-9.

21. Zamany A, Spangberg LS. An effective method of inactivating chlorhexidine. Oral Surg Oral Med Oral Path Oral Radio Endod 2002;93(5):617-20.

22. Patterson S. In vivo and in vitro studies on the effect of the disodium salt of ethylene diamine tetra-acetate on human dentin and its endodontic implication. Oral Surgery Med Oral Path 1963;16:83-103.

23. Vahdaty A, Ford PTR, Wilson RF. Efficacy of chlorhexidine in disinfecting dentinal tubules in vitro. Endodontic Dental Traumatol 1993;9(6):243-8

24. White R, Goldman M. Influence of the smeared layer on dentinal tubule penetration by various root canal sealers. Jour Dent Res 1983;62(417):215.

25. Zehnder M, Schmidlin P, Sener B, et al. Chelation in root canal therapy reconsidered. J Endod 2005;31(11):817-20.

26. Nikiforuk G, Sreebny L. Demineralization of hard tissue by organic chelating agents at neutral $\mathrm{pH}$. Journal Dental Restoration 1953;32(6):859-67. 
27. Heling B, Shapirdo S, Sciaky I. An invitro comparison of the amount of calcium removed by the disodium salt EDTA and hydrochloric acid during endodontic procedures. Oral Surgery Oral Medical Oral Path 1965;19(4);531-3.
28. Dalton GW. Chlorhexidine. In: Block SS. Disinfection, sterilization and preservation. $4^{\text {th }}$ edn. Philadelphia: Lea and Febiger 1991:274-89. 